\title{
Measurement Of Students Attitude Towards Statistics: A Mokken Scales Analysis Of Its Dimensions
}

Manuel Vargas-Vargas, Ph.D., University of Castilla-La Mancha, Spain José Mondéjar Jiménez, Ph.D., University of Castilla-La Mancha, Spain $M^{a}$ Leticia Meseguer-Santamaría, University of Castilla-La Mancha, Spain José-María Montero-Lorenzo, Ph.D., University of Castilla-La Mancha, Spain Gema Fernández-Avilés, Ph.D., University of Castilla-La Mancha, Spain

\begin{abstract}
Nowadays, almost all curricula in the social sciences contain at least one course in statistics, given the importance of this discipline as a basic knowledge to understand the modern world. It's necessary reflects on the student's attitude to statistics, because it's could be an obstacle or an advantage in their learning process. To measure the student's attitude and incentives about statistics, we use a test (Bayot et al., 2005), related to other ones which exists in the specialized literature, that identifies the latent factors relating to students' motivation and attitude towards statistics. This paper describes the formal and metric characteristics of the non-parametric model of item response theory for the latent factors using an extension of Mokken scales analysis.
\end{abstract}

Keywords: Learning Statistic; Latent factors; Non-Parametric Item Response Model; Mokken Scales Analysis

\section{INTRODUCTION}

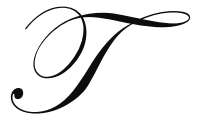

he influence of cognitive and affective factors in the students' attitude and performance in the learning of statistics has been widely discussed in the literature (Roberts and Saxe, 1982; Beins, 1985; Wise, 1985; Katz and Tomezik, 1988; Gil, 1999; Bayot et al., 2005; Mondéjar, Vargas and Bayot, 2008; Mondéjar and Vargas, 2010). However, there is still no consensus on the theoretical foundation of this influence (Carmona, 2004), nor on how to operationalize concepts that have different shades and are not directly observables. Following Auzmendi (1992, p. 17), we mean attitudes as "aspects are not directly observable but inferred, made both by the beliefs and the feelings and behavioral predispositions toward the object at that address". The most important attitudes are those of the affective component - the domain in which researchers have shown most interest. Several works study the anxiety construct in education and its relation with academic performance (Seipp, 1991; Hardy and Hagtvet, 1996), and show that modify the students' level of anxiety can translate into improved academic performance.

In this paper, we use a questionnaire about attitude towards statistics developed in Bayot et al. (2005), which decomposes attitude into two subscales, one affective and the other evaluative, both bi-dimensional in structure. In the affective subscale, one factor measures the degree of interest in the subject, and the other, the level of students' anxiety when tackling statistics problems. The valorative subscale also consists of two components, one measuring the utility students perceive for their current studies, and the other, the utility for their future professional career. This latent structure is similar to other scales proposed in the literature (Wise, 1985; Waters et al., 1988; Elmore and Lewis, 1991; Woehlke, 1991; Auzmendi, 1992; Schau et al., 1995; Gil, 1999; Darias, 2000). In these works, the structure always contains factors relating to both the affective and evaluative components, but they tend to disagree on the number of variables they use to operationalize each component. Searching out existing standard scales and measures for constructs is therefore often an important early step in the research process. 
While in the education literature are not consensus on how to operationalize these constructs (often there is no one perfect way to operationalize its), the developed scales should be validated and their phicometric characteristics analysed. If scales are defined as sets of items which stand in ordinal relationship to each other, then Mokken scales meet this test of ordinality between items. In this case, the coefficients of scalability and reproducibility are tests of whether items are sufficiently in an ordinal relationship to justify their combination in an index (Mokken and Lewis, 1982). Loevinger's coefficient H measures the conformity of a set of items to Mokken's criteria and validates their use together as a scale of a unidimensional latent variable (Sijtsma and Verwey, 1992).

The aim of this paper is to evaluate the quality metrics of the used questionnaire for measuring students' attitudes towards statistics, adapted to the proposed structure. Specifically, each of the four dimensions should consist of items that are added one-dimensional and which satisfy the monotonous uniformity. To this end, we applie a nonparametric item response model which generalizes that of Mokken (Mokken, 1971, 1997), called strong model of double monotony (Sitjsma and Hemken, 1998), given the nature of the data obtained by the Bayot et al. questionnaire.

\section{DATA COLLECTION AND METHOD}

The empirical study uses a sample of 374 students from the University of Castilla-La Mancha (Spain) enrolled on a unit with statistical content for the first time during their university studies. The study has an ex-postfacto design, and took place in the second week of classes, in order to ensure that the results were not biased by factors such as the progress of the unit, the performance of the teacher, or the partial results obtained.

Mokken model, and its derivates, assuming the existence of a latent scale $(\theta)$ related to the empirical scale used as measure $(\mathrm{X})$, usually obtained by adding the scores of each of the items. But it needs some metric conditions to ensure the inferences made based on the first by the second (Elosua, 2006):

- $\quad$ Stochastic Ordering of Empirical Scale (SOES). The order of individuals on the latent scale produces a stochastically correct order on the empirical scale. Given two individuals, A and B, with levels in the latent scale $\theta_{\mathrm{A}}$ and $\theta_{\mathrm{B}}$ such that $\theta_{\mathrm{A}}<\theta_{\mathrm{B}}$, this property states that for any empirical score $\mathrm{x}$ :

$P\left(X \geq x / \theta_{A}\right) \leq P\left(X \geq x / \theta_{B}\right)$

- $\quad$ Stochastic Ordering of Latent Scale (SOLS). The order of individuals on the empirical scale produces a stochastically correct order of individuals on the latent scale. For a constant value in the latent variable (s) and for two empirical values $\mathrm{x}_{1}$ and $\mathrm{x}_{2}$ such that $\mathrm{x}_{1}<\mathrm{x}_{2}$ :

$\mathrm{P}\left(\theta>\mathrm{s} / \mathrm{X}=\mathrm{x}_{1}\right)<\mathrm{P}\left(\theta>\mathrm{s} / \mathrm{X}=\mathrm{x}_{2}\right)$

The evaluation of these conditions is based on empirical verification of some properties. The monotony can be assessed by the Loevinger's scalability coefficient, $\mathrm{H}_{\mathrm{ij}}$ :

$H_{i j}=1-\frac{\sum_{i} \sum_{j} w_{i j} n_{o i j}}{\sum_{i} \sum_{j} w_{i j} n_{e i j}}$

where $\mathrm{w}_{\mathrm{ij}}$ is the number of errors in the pattern $\mathrm{ij}, \mathrm{n}_{\mathrm{oij}}$ is the number of responses observed in the response pattern $\mathrm{ij}$ and $\mathrm{n}_{\mathrm{eij}}$ is the number of expected responses in the pattern $\mathrm{ij}$ under the assumption of independence.

Although there is a test for evaluate their significance (Molenaar and Sijstma, 2000), because of low power, it is usual to consider values equal to or above 0.3 as significant (Mokken, 1971). 


\section{STATISTICAL RESULTS}

To evaluate the psychometric properties of the questionnaire on attitudes towards statistics of Bayot et al. (2005), we have estimated the coefficients of scalability, Hi, by the software routine Mokken for statistical software R.

Table 1 shows factorial structure of the questionnaire, obtained by factorial analysis (Mondéjar and Vargas, 2010). Each empirical scale is estimated by aggregation of items, weighted by rotated factor loadings.

Table 1: Rotated Factor Loadings

\begin{tabular}{|c|c|c|c|c|c|}
\hline Item & F1: Interest & F2: Anxiety & Item & F3: Pres. Util. & F4: Proff. Util \\
\hline Item $\mathrm{n}^{\circ} 15$ & 0.764 & & Item $\mathrm{n}^{\circ} 10$ & 0.690 & \\
\hline Item $\mathrm{n}^{\mathrm{o}} 17$ & 0.759 & & Item $\mathrm{n}^{\circ} 25$ & 0.655 & \\
\hline Item $\mathrm{n}^{\circ} 14$ & 0.737 & & Item $\mathrm{n}^{\circ} 16$ & 0.593 & \\
\hline Item $\mathrm{n}^{\mathrm{o}} 13$ & 0.735 & & Item $\mathrm{n}^{\circ} 3$ & 0.533 & \\
\hline Item $n^{\circ} 24$ & 0.671 & & Item $^{\circ} 5$ & & 0.746 \\
\hline Item $\mathrm{n}^{\circ} 18$ & 0.537 & & Item $\mathrm{n}^{\circ} 20$ & & 0.679 \\
\hline Item $n^{\circ} 9$ & & 0.735 & Item $^{\circ}{ }^{\circ} 11$ & & 0.555 \\
\hline Item $\mathrm{n}^{\circ} 7$ & & 0.722 & Item $\mathrm{n}^{\circ} 26$ & & 0.552 \\
\hline Item n ${ }^{\circ} 22$ & & 0.706 & Item $\mathrm{n}^{\circ} 6$ & & 0.550 \\
\hline Item $n^{\circ} 21$ & & 0.702 & Item $\mathrm{n}^{\circ} 4$ & & 0.520 \\
\hline Item $n^{\circ} 23$ & & 0.643 & Item $n^{\circ} 2$ & & 0.519 \\
\hline Item $n^{\circ} 12$ & & 0.633 & Item ${ }^{\circ} 19$ & & 0.501 \\
\hline Item $\mathrm{n}^{\mathrm{o}} 1$ & & 0.557 & Item $\mathrm{n}^{\circ} 27$ & & 0.497 \\
\hline
\end{tabular}

To assess the monotonicity of the four empirical scales, Loevinger's scalability coefficients, $\mathrm{H}_{\mathrm{ij}}$, were estimated for each pair of items. From them, we obtain the scalability coefficients for each item, $\mathrm{H}_{\mathrm{i}}$, adding the corresponding $\mathrm{H}_{\mathrm{ij}}$ for all other items, as shown in Table 2:

Table 2: Loevinger's Scalability Coefficients $\mathbf{H}_{\mathrm{i}}$

\begin{tabular}{|c|c|c|c|c|c|}
\hline Item & F1: Interest & F2: Anxiety & Item & F3: Pres. Util. & F4: Proff. Util \\
\hline Item $n^{\circ} 15$ & 0.587 & & Item $n^{\circ} 10$ & 0.433 & \\
\hline Item $n^{\circ} 17$ & 0.600 & & Item $^{\circ} 25$ & 0.383 & \\
\hline Item $n^{\circ} 14$ & 0.594 & & Item $\mathrm{n}^{\circ} 16$ & 0.409 & \\
\hline Item $\mathrm{n}^{\mathrm{o}} 13$ & 0.565 & & Item $n^{\circ} 3$ & 0.369 & \\
\hline Item $n^{\circ} 24$ & 0.543 & & Item $n^{\circ} 5$ & & 0.295 \\
\hline Item $n^{\circ} 18$ & 0.426 & & Item $^{\circ} 20$ & & 0.283 \\
\hline Item $n^{\circ} 9$ & & 0.469 & Item $\mathrm{n}^{\circ} 11$ & & 0.438 \\
\hline Item $\mathrm{n}^{\circ} 7$ & & 0.450 & Item $^{\circ} 26$ & & 0.492 \\
\hline Item $n^{\circ} 22$ & & 0.492 & Item $n^{\circ} 6$ & & 0.420 \\
\hline Item $n^{\circ} 21$ & & 0.491 & Item $n^{\circ} 4$ & & 0.449 \\
\hline Item $n^{\circ} 23$ & & 0.417 & Item $\mathrm{n}^{\circ} 2$ & & 0.444 \\
\hline Item $\mathrm{n}^{\circ} 12$ & & 0.418 & Item $^{\circ}{ }^{\circ} 19$ & & 0.317 \\
\hline Item $n^{\circ} 1$ & & 0.378 & Item $^{\circ}{ }^{\circ} 27$ & & 0.382 \\
\hline
\end{tabular}

Finally, we estimate the scalability coefficients for each empirical scale adding the $\mathrm{H}_{\mathrm{i}}$ for the constitutive items. Table 3 shows, for each factor, the Loevinger's coefficients $\mathrm{H}$, and the empirical mean and standard desviation. 
Table 3: Coefficient H, Mean and Standard desviation of escales

\begin{tabular}{|l|c|c|c|}
\hline \multicolumn{1}{|c|}{ Scale } & H & Mean & Standard Desviation \\
\hline F1: Interest & 0.5555 & 2.56 & 0.92 \\
\hline F2: Anxiety & 0.4469 & 3.26 & 1.00 \\
\hline F3: Present utility & 0.3979 & 3.40 & 0.98 \\
\hline F4: Professional utility & 0.4213 & 3.47 & 0.93 \\
\hline Total of escales & & 3.17 & 0.96 \\
\hline
\end{tabular}

In all cases, the scalability coefficients are significant, indicating that the obtained empirical scales adhere to the principle of monotonicity. This ensures the one-dimensional for the empirical scales, reflecting the existence of latent scales for each of the dimensions analyzed (Junker and Sijtsma, 2000).

In a descriptive analysis of the scales, we note the low level of interest in statistics, they find most useful for their future careers than for their present studies. Also, the raised level of anxiety in students is above the central value of the scale.

\section{CONCLUSIONS}

In this paper, we have evaluated the psychometric properties of a questionnaire designed to assess students' attitudes towards statistics. The questionnaire has two subscales, an affective and other evaluative, both with twodimensional structure. In all cases, the Loevinger's scalability coefficients, $\mathrm{H}$, are close to or above 0.4 , indicating that the obtained factor structure is appropriate: the four empirical scales are significant, monotonous and consist of items that are added unidimensionally. Thus, the estimate scales can be used as a substitute for latent scales in the study of affective and evaluative components that influence students' attitudes towards statistics.

Globally, the results confirm a model that can offer guidance about how educators can reduce students' level of anxiety with respect to statistics. Specifically, if educators can familiarize their students about the social applications of statistics, this should reinforce their perception of the utility of this discipline for their current studies and increase their interest in studying the subject. These effects should indirectly translate into a reduction in the students' level of anxiety. Likewise, efforts to directly boost students' interest in statistics or their perception of its utility in their current studies should also reduce their level of anxiety.

Efforts to reduce the level of anxiety-nervousness should lead to improved academic performance in statistics among students, so this model could help educators design strategies to do this, or provide a means of evaluating the effectiveness of such strategies.

\section{AUTHOR INFORMATION}

Manuel Vargas-Vargas: PhD in Economics by University of Castilla-La Mancha and Degree in Mathematics by University of Granada. Associate Professor in Statistics at Statistics Department. Faculty of Economics and Business Administration of Albacete, University of Castilla-La Mancha (Spain). E-mail: Manuel.Vargas@uclm.es. Research Interest: disability, regional analysis, educational and tourism.

José Mondéjar-Jiménez: European $\mathrm{PhD}$ in Economics and Degree in Business Administration by University of Castilla-La Mancha. Associate Professor at Statistics Department. Faculty of Social Sciences of Cuenca. University of Castilla-La Mancha (Spain). E-mail: Jose.Mondejar@uclm.es.

Research Interest: disability, regional analysis, educational and tourism. 
María-Leticia Meseguer-Santamaría: MBA in Economics Degree in Business Administration by University of Castilla-La Mancha. Assistant Professor in Statistics at Statistics Department. Faculty of Economics and Business Administration of Albacete. University of Castilla-La Mancha (Spain). E-mail: MLeticia.Meseguer@uclm.es.

Research Interest: disability, women studies, educational and tourism.

José-María Montero: He is PhD in Economics and Business Administration, Autonomous University of Madrid, Spain. Currently his position is Full Professor in Statistics at the Department of Statistics, Faculty of Law and Social Sciences, University of Castilla-La Mancha, Spain. E-mail: Jose.MLorenzo@uclm.es.

Research Interest: qualitative data, geostatistics, educational and tourism.

Gema Fernández-Avilés: She is European PhD in Economics and Business Administration, University of CastillaLa Mancha, Spain. Currently his position is Assistant Professor in Statistics at the Department of Statistics, Faculty of Law and Social Sciences, University of Castilla-La Mancha, Spain. E-mail: Gema.FAviles@uclm.es.

Research Interest: qualitative data, geostatistics, educational and tourism.

\section{REFERENCES}

1. Auzmendi, E. (1992). Las actitudes hacia la matemática-estadística en las enseñanzas medias y universitarias. Bilbao: Mensajero.

2. $\quad$ Bayot, A.; Mondéjar, J.; Mondéjar, J.A.; Monsalve, F. and Vargas, M. (2005). The Difficulties of Learning Concepts in the Social Sciences. In Misztal, M. and M. Trawinski (eds.) Studies in Teacher Education: Psichopedagogy, 242-258. Kraków: Wydawnictwo Naukowe Akademii Pedagogicznej.

3. Beins, B.C. (1985). Teaching the relevance of statistics trough consumer-oriented research. Teaching of Psychology, 12, 168-169.

4. Carmona, J. (2004). Una revisión de las evidencias de fiabilidad y validez de los cuestionarios de actitudes y ansiedad hacia la estadística. Statistics Education Research Journal, 3(1), 5-28.

5. $\quad$ Darias, E. (2000). Escala de actitudes hacia la estadística. Psicothema, 12 (2), 175-178.

6. DeVellis, R. F. (2003). Scale development: Theory and applications, Second edition. Thousand Oaks, CA: Sage Publications.

7. Elosua, P. (2006). Modelo de doble monotonía fuerte para ítems politómicos aplicado a una escala de autoconcepto social. Propiedades formales y métricas. Revista electrónica de metodología aplicada, 11(1), $1-15$.

8. Gil, J. (1999). Actitudes hacia la estadística. Incidencia de las variables sexo y formación previa. Revista española de pedagogía, LVII, 214, 567-590.

9. Junker, B. W. and Sijtsma, K. (2000). Latent and Manifest Monotonicity. Applied Psychological Measurement, 24, 65-81.

10. Katz, B. M. and Tomazic, T. Z. (1988). Changing student's attitudes toward statistics through a nonquantitative approach. Psichological Reports, 62, 658.

11. Mokken, R. J. (1971). A theory and procedure of scale analysis. The Hague, The Netherlands: Mouton.

12. Mokken, R. J. (1997). Nonparametrics models for dichotomous responses. In W. J. van der Linden and R. K. Hambleton (Eds.). Handbook of Modern Item Response Theory. New York, USA: Springer.

13. Mokken, R. J. and Lewis, C. (1982). A non parametric approach to the analysis of dichotomous item responses. Applied Psychological Measurement, 6, 417-430.

14. Mondéjar, J. and Vargas, M. (2010). Determinant factors of attitude towards quantitative subjects: Differences between sexes. Teaching and Teacher Education, 26(3), 688-693.

15. Mondéjar, J.; Vargas, M. and Bayot, A. (2008). Medición de la actitud hacia la estadística. Influencia de los procesos de estudio. Revista Electrónica de Investigación Psicoeducativa, 6 (3), 729-748.

16. Moolenar, W. and Sijtsma, K. (2000). MSP5 for windows. Groningen: iecProGAMMA.

17. Roberts, D. M. and Saxe, J. E. (1982). Validity of a statistics attitude survey: a follow-up study. Educational and Psichological Measurement, 42, 907-912.

18. Schau, C., Stevens, J., Dauphinee, T. L. and Del Vecchio, A. (1995). The Development and Validation of the Survey of Attitudes toward Statistics. Educational and Phychological Measurement, 55 (5), 868-875.

19. Seipp, B. (1991). Anxiety and academic performance: A meta-analysis of findings. Anxiety Research, 4 , $27-41$. 
20. Sijtsma, K. and Hemker, B. T. (1998). Nonparametric Polytomous IRT models for invariant item ordering, with results for parametric models. Psychometrika, 63(2), 183-200.

21. Sijtsma, K. \& Molenaar, I. W. (2002). Introduction to Nonparametric Item Response Theory. Thousand Oaks, CA.: Sage.

22. Sijtsma, K. and Verwey, A. (1992). Mokken scale analysis; theoretical considerations and an application to transitivity tasks. Applied Measurement in Education, 5(4), 355-373.

23. Van Abswoude, A., Van der Ark, L. and Sijtsma, K. (2004). A Comparative Study of Test Data Dimensionality Assessment Procedures Under Nonparametric IRT Models. Applied Psychological Measurement, 28, 3-24.

24. Waters. L. K., Martelli, T. A., Zakrajsek, T. and Popovich, P. M. (1988). Factor analyses of two measures of attitudes toward statistics. Educational and Psychological Measurement, 48, 1037-1041.

25. Wise, S. (1985). The development and validation of a scale measuring attitudes toward statistics. Educational and Psychological Measurement, 45, 401-405. 